\title{
An assessment of crop residue characteristics and factors militating against efficient management in the Ikara local government area of Kaduna state, Nigeria
}

\author{
E. I. Aruya ${ }^{1}$, R. O. Yusuf ${ }^{1} \&$ Y. O. Yusuf ${ }^{2}$ \\ ${ }^{1}$ Department of Geography, Ahmadu Bello University, Nigeria \\ ${ }^{2}$ Department of Geography, Federal University, Nigeria
}

\begin{abstract}
This study assessed the nature of crop residues and factors militating against its management in Ikara local government area. The ten wards in the study area were used for the study. A sample of 380 farmers was surveyed by means of a questionnaire which was administered using convenient sampling techniques based on population size. The study revealed that in Ikara LGA, Kurmin Kogi has the highest amount of crop residue with $48,328 \mathrm{~kg}$ amounting to $26.20 \%$ of the total crop residue generated. It was also observed that cereals contributed the highest source of crop residue with maize, millet and guinea corn as the major constituents. The study also shows that most of the farming households still engage in inefficient management practices such as open dumping and burning of their agricultural waste. However, there still exist some efficient agricultural waste management in the study area as some farmers reuse their crop remnants. Nearly one-third of the farmers reported that lack of awareness or ignorance of the benefits and strategies of crop residue management is one of the reasons for poor utilization of crop residues in the study area. The current management option is not perfect and the existing framework to ensure adequate management system and the collection facilities is not available. Crop waste is still collected without separation at the source, treatment facilities are limited and the collected waste is mostly dumped haphazardly in open areas or in most cases burnt before the next farming season. It is suggested that intensive mass literacy programmes on the economics of crop residue management be undertaken in the study area. Also, by involving the farmers and other stakeholders, the
\end{abstract}


government should come up with appropriate policies and legislative measures to discourage dumping and burning of crop waste.

Keywords: waste, crop residue, management, environment, Ikara local government area.

\section{Introduction}

The by-products of agricultural activities are usually referred to as "agricultural waste" because they are not the primary products. This waste chiefly takes the form of crop residues (residual stalks, straw, leaves, roots, husks, shells, etcetera) and animal waste (manure). Agricultural waste management is the collection, transportation, processing, treatment, recycling or disposal of agricultural waste materials to reduce their adverse effects on human health, amenities and environment. Agricultural waste represents valuable resources as ground cover to reduce erosion, fertilizer to nourish the crops, source of energy among others [1].

Crops residues include remnants obtained during harvesting and crop processing waste. With advances in biotechnology and bioengineering, some resources, which could have been classified as waste, now form the basis for energy production [2]. It is estimated that, Nigeria has about 71.2 million hectares of available agricultural land, out of which about 36 million hectares of land are being currently utilized for agricultural production [3]. The large quantities of crop residues produced in Nigeria can play a significant role in meeting its energy demand. Most of these residues are biomass, which contains enormous amounts of energy [4]. However, it is unfortunate that these residues are neither utilized efficiently nor properly managed effectively in all developing countries, including Nigeria [5]. The prevailing practice is usually to burn this waste or leave it to decompose. This burning or decomposition, apart from amounting to a colossal waste of resources, contributes to environmental degradation and pollution and this poses hazards to both humans and the environment.

Crop residue management is a growing public concern in many countries in Africa, including Nigeria [6]. The first goal of any crop residue management system is to maximize the economic benefit from the waste resource and maintain acceptable environmental standards. To be practical, the system must also be affordable and suitable to the environment. Agricultural crop residues characteristics and management have been well investigated in European and American agricultural cultures. However, investigation of these issues for academic and policy purposes in many developing countries is usually taken for granted. For sustainable agricultural and environmental management, such issues can no longer be overlooked. That is the basis of this study using Ikara local government area of Kaduna state as the spatial focus.

\subsection{Research problem}

A major challenge for many countries is how to increase agricultural production without degrading the environment. This is a global issue; hence there should be 
a greater adoption of environment-friendly intervention and technology in massive food production [7]. One of such environment friendly intervention is effective management of crop waste. In addition, many farmers now view the practice of residue utilization for energy regeneration as an extra cost with small returns, and that the best way is to get rid of the residues is a least effort method like dumping, open burning and others [8]. But the hazards to the environment by such practices can no longer be ignored. This is even more appropriate as a number of agricultural and biomass studies have concluded that it may be appropriate to remove and utilize at least a portion of these residues for energy production, providing a large volume of low cost materials [9].

A number of related studies are accessible and a few of them are examined to put this study in proper perspective. A study by Kwaghe et al. [10] on economic analysis of agricultural waste management among farming households in Jere local government area of Bornu State, Nigeria, showed that about $62.5 \%$ of respondents generate crop residues while reuse is the major waste management method while other farmers still practice dumping and burning of their farm waste. The quantities of crop residues were 161. It is also suggested that government should involve the farmers and other stakeholders to come up with appropriate policies and legislative measures to discourage dumping and burning of agricultural waste.

Informed opinion and observation revealed that the level of crop residue management and recycling in Kaduna state and Ikara local government area is very low. This could be as a result of inadequate knowledge on crop waste disposal, management and recycling strategies by the farmers [11]. More importantly, inadequate understanding of the characteristics, volume and other attributes of crop residues make it difficult to adopt sustainable management approaches. Also Ikara like any other northern Nigerian society is agrarian where several tons of crop waste, considering HRWC [12] position on waste management are either abused or left unused. This is the gap this research intends to fill to advance the frontier of knowledge on waste management, sustainable agricultural practices and environmental policy making processes.

\subsection{Study area}

Ikara is located on Lat. $11^{\circ} 22^{\prime} \mathrm{N}$ and $11^{\circ} 31^{\prime} \mathrm{N}$ of the equator and Long. $8^{\circ} 21^{\prime} \mathrm{E}$ and $8^{\circ} 28^{\prime} \mathrm{E}$ of the Greenwich meridian. Ikara has seven (7) districts namely, Ikara, Saulawa, Auchan, Kurmin Kogi, Furana, Pala and Paki (see Fig. 1) and ten (10) wards which are Ikara, Janfalan, Pala, Kurmin Kogi, Saulawa Rumi, Auchan, Kuya, Paki and Saya-Saya. Ikara lies on the high plains of Hausa land, of height ranging from 550 to 750meters showing a general regional slope to the south and a relative relief of 30 to 45 meters. The area is drained by river Kaduna and characterized by high stream frequencies and drainage density. Ikara has a tropical continental climate. The annual rainfall is about $1200-1400 \mathrm{~mm}$ and the seasonal characteristics affect the vegetal cover [13]. The economy of Ikara local government area revolves around agriculture. About $80 \%$ of the population in the study area engage in farming. The agricultural activity in the study area can be categorized into arable, tree crop and livestock farming. Crop farming is the 
main agricultural activity in the area. Crops are produced both during the rainy and the dry season. A lot of farming takes place in the study area where most of the farm products supplied to the capital city of Kaduna are produced [14].

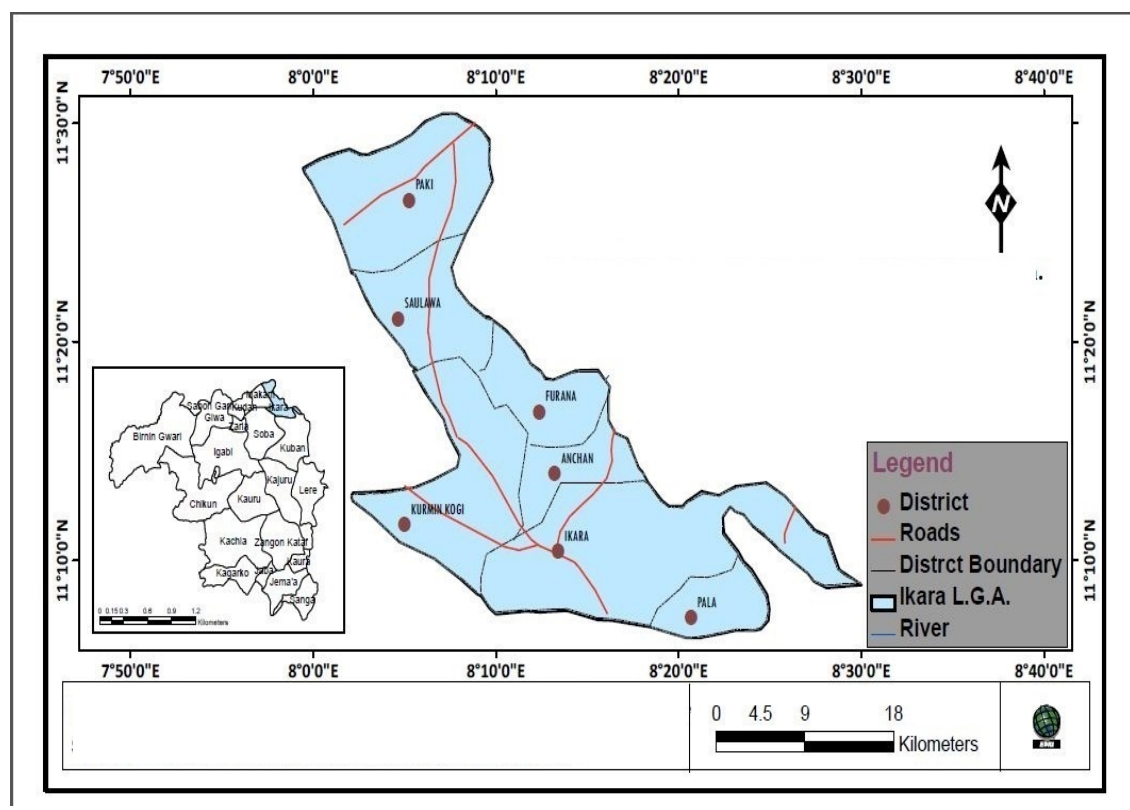

Figure 1: Ikara local government area: study area. (Source: modified from the administrative map of Kaduna state.)

\section{Methodology}

In order to achieve the aim and objectives of the study, the research utilized majorly primary data. A pretext questionnaire was administered to 380 respondents across the ten (10) wards in the study area which are Ikara, Saulawa, Auchan, Kurmin/Kogi, Janfalan, Pala, Saya-Saya, Kuya, Rumi and Paki using the Krejcie and Morgan (1970) method of determination of sample size. The questionnaire was administered using a convenient sampling technique whereby allocating the questionnaire to respondents was based on population size per ward.

Data entry, coding, cleaning and test for normality was made following standardized procedures. Quantitative and qualitative statistical methods were employed to analyze the information collected from the field. In order to examine the factors militating against efficient waste management in the area, content analysis of response obtained from farmers was undertaken which are later subjected to descriptive statistics such as tabulation. All statistical analysis was carried out using SPSS 17. Statistical test for significance was carried out at $5 \%$ level of significance. 


\section{Results and discussion}

\subsection{Socio-economic characteristics of farmers}

The socio-economic characteristics of the respondents include the sex, age, occupation of farmers other than farming and educational qualification of farmers. Table 1 shows that the farmers at Ikara local government area are predominantly male as attested by $96 \%$ of the farmers, this is basically as a result of the cultural and religious setting limiting the involvement of female farmers in most rural areas in the Hausa dominated Muslim communities in northern Nigeria as deduced from the responses of the $4 \%$ females.

It was also observed that $49 \%$ of the farmers in the study area are over 40 years old, $20 \%$ are within the age bracket of $31-40$ while $31 \%$ fall within the age bracket of 21-31, which indicates that most of the farmers are old and apart from $20 \%$ and $27 \%$ that engage in civil service and business enterprises other than farming, $42 \%$ are solely farmers. Indeed, as revealed by Table 1D, 19\% of the respondents have no formal education, 28\% have Quranic education, 32\% have attained first school certificate, $17 \%$ have attained SSCE while $4 \%$ have acquired tertiary qualifications. The farmers with tertiary certificates are all located in the local government headquarter and are predominantly subsistence based.

Table 1E shows the responses of farmers with respect to the type of agriculture practiced. From the responses it was clearly observed that $96 \%$ of the farmers in the study area are predominantly subsistence while $4 \%$ are commercial. However, it was also observed that most subsistent farmers also sell some of their products, although on a very small scale. On the other hand, $4 \%$ of the respondents are commercial farmers and they make use of large area of land and are usually involved in both crop farming and animal rearing for commercial purposes. Table 1F shows the acres of land used by farmers in the study area. It can be clearly seen that because of the small scale nature of farming of the farming households, most of the farmers in the study area use 1-5 acres of land as attested by $87 \%$ of the respondents.

In the socio-economic characteristics of the respondents, it can be clearly seen that Ikara LGA depicts the true characteristics of a rural settlement, characterized by low educational qualification. It however, contradicts other characteristics of rural areas as portrayed by Solano et al. [15] that rural areas are where the youths have migrated or classify rural areas as zones of high propensity for out migration because in the study area over $51 \%$ of the respondents are youths actively involved in agriculture, although they combine it with trading and schools. 
Table 1: Socio-economic characteristics of respondents in the study area.

\begin{tabular}{|c|c|c|}
\hline A. Sex & Frequency & $\begin{array}{c}\text { Percentage } \\
(\%)\end{array}$ \\
\hline Male & 364 & 96 \\
\hline Female & 16 & 04 \\
\hline Total & 380 & 100 \\
\hline B. Age & Frequency & $\begin{array}{c}\text { Percentage } \\
(\%)\end{array}$ \\
\hline $20-30$ & 116 & 31 \\
\hline $31-40$ & 77 & 20 \\
\hline 41 and above & 187 & 49 \\
\hline Total & 380 & 100 \\
\hline $\begin{array}{l}\text { C. Occupation of farmers other } \\
\text { than farming }\end{array}$ & Frequency & $\begin{array}{c}\text { Percentage } \\
(\%)\end{array}$ \\
\hline Civil servant & 74 & 20 \\
\hline Business & 104 & 27 \\
\hline Student & 36 & 09 \\
\hline Others & 06 & 02 \\
\hline None & 160 & 42 \\
\hline Total & 380 & 100 \\
\hline D. Educational qualification & Frequency & $\begin{array}{c}\text { Percentage } \\
(\%)\end{array}$ \\
\hline No formal education & 74 & 19 \\
\hline Quranic school & 106 & 28 \\
\hline Primary & 122 & 32 \\
\hline Secondary & 63 & 17 \\
\hline Tertiary & 15 & 04 \\
\hline Total & 380 & 100 \\
\hline E. Type of farmer & Frequency & $\begin{array}{c}\text { Percentage } \\
(\%)\end{array}$ \\
\hline Subsistence & 364 & 96 \\
\hline Commercial & 16 & 04 \\
\hline Total & 380 & 100 \\
\hline F. $\quad$ Farm size in acres & Frequency & $\begin{array}{c}\text { Percentage } \\
(\%)\end{array}$ \\
\hline $1-5$ acre & 329 & 87 \\
\hline $6-10$ acre & 46 & 12 \\
\hline $11-15$ acre & 05 & 01 \\
\hline Total & 380 & 100 \\
\hline
\end{tabular}

Source: field survey 2014.

\subsection{Characteristics and composition of crop residue in the study area}

Table 2 revealed that corncobs are the major residue generated with $25.53 \%$. The corncobs residue is made up of maize, sorghum and millet. While the least crop 
residue generated are tree trimmings with $2.89 \%$. Corn is the major crop planted in the study area, because of the environmental advantage and its high demand in the area under study. Hence, this accounts for corn cobs being the most commonly generated crop residue in the study area.

Table 2: $\quad$ Type of crop waste generated in the study area.

\begin{tabular}{|lcc|}
\hline Type of crop waste & Frequency & Percentage (\%) \\
\hline Corncobs & 97 & 25.53 \\
Sugarcane bagasse & 59 & 15.53 \\
Groundnut shells & 70 & 18.42 \\
Leaves and grasses & 28 & 7.37 \\
Other crop residues & 102 & 26.84 \\
Tree trimmings & 11 & 2.89 \\
No response & 13 & 3.42 \\
\hline Total & $\mathbf{3 8 0}$ & $\mathbf{1 0 0}$ \\
\hline
\end{tabular}

Source: field survey 2014.

\subsection{Volume of crop residue in the study area}

Table 3 presents the estimated quantity (kilograms) of crop residue generated in the study area by the farming households. The total volume of crop residue generated in 2013 is $184,500 \mathrm{~kg}$. From table 3 it can also be clearly seen that farmers in Kurmin Kogi generate the highest volume of crop residue $(48,328 \mathrm{~kg}$ ) equivalent to $26.19 \%$ of the total. This is because most farming households are commercial responsible for producing most of the food crops sold and consumed in the study area and marketed at nearby urban centres like Makarfi, Kubau and Kaduna (the state capital). The crop residue from Ikara and Saulawa wards are $27,450 \mathrm{~kg}$ and $23,627 \mathrm{~kg}$ respectively. It can also be observed that despite the population of farming households considered in Ikara, its percentage contribution in relation to other wards is $14.87 \%$. This is because it is the most urbanized part of the LGA, hence other land uses affect land for farming.

The work of Kwaghe et al. [10] revealed that the estimated quantity/tonnage of agricultural waste for farming households in Jere local government area of Borno State is 264 tonnes $(264,000 \mathrm{~kg})$ with crops accounting for 161 tonnes $(161,000 \mathrm{~kg})$ of waste and animals accounting for 103 tonnes $(161,000 \mathrm{~kg})$ of waste. This shares close similarities with the quantity of crop residue generated in Ikara local government area though with higher values which may be attributed to the difference in ecological zone. Ikara is in the north central while Jere is in the north east. 
Table 3: Volume of crop waste generated in the study area.

\begin{tabular}{|lcc|}
\hline Wards & $\begin{array}{c}\text { Estimated volume of } \\
\text { crop waste (Kg) }\end{array}$ & $\begin{array}{c}\text { Percentage in relation to } \\
\text { other wards (\%) }\end{array}$ \\
\hline Ikara & 27,450 & 14.87 \\
Saulawa & 23,627 & 12.81 \\
Auchan & 12,345 & 6.69 \\
KurminKogi & 48,328 & 26.19 \\
Janfalan & 12,000 & 6.50 \\
Pala & 4,500 & 2.44 \\
Saya-Saya & 21,350 & 11.57 \\
Kuya & 3,800 & 2.06 \\
Rumi & 7,600 & 4.13 \\
Paki & 23,500 & 12.74 \\
Total & $\mathbf{1 8 4 , 5 0 0}$ & $\mathbf{1 0 0}$ \\
\hline
\end{tabular}

Source: field survey 2014.

\subsection{Sources of crop residue in the study area}

In the study area several crops were responsible for the residue generated. Figure 2 revealed that cereals are the major source of these residues with maize, millet and guinea corn as the major constituents as attested to by $49 \%$ of the respondents. Similarly, root crops such as sweet potatoes and Irish potatoes accounted for $16 \%$ of the crop residue. However, when post-harvest waste of potatoes is compared with its original planting quantity it was realized that potatoes gets to the final consumer almost without undergoing much post-harvest handling. Irish potatoes although not favourable to the climatic condition, were found grown in Kurmin Kogi and Janfalan wards. Vegetables and sugarcane contributed $12 \%$ and $13 \%$ of the crop residue generated while $10 \%$ was

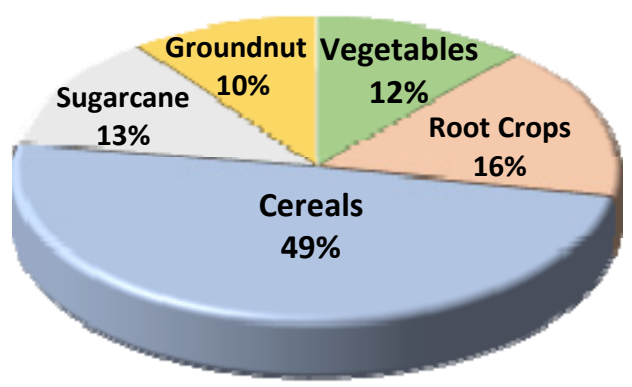

Figure 2: $\quad$ Sources of crop residue in the study area. 
contributed by groundnut. Based on the type of waste generated after sorting, it can be deduced that maize is the major crop planted in the 2013 farming season in Ikara local government area of Kaduna state. This was subsequently confirmed through personal interview with the farmers and data obtained from the questionnaire survey.

The result obtained differs from the work of Adeoye et al. [16] in Minna, Niger State where the researchers found out that groundnut was the major contributor of crop residue in Kontagora zone, rice was the major contributor in Bida zone and maize is the major contributor in Shiroro zone. The result however shares close similarity with that of Kwaghe et al. [10], in Jere local government area of Borno state where maize was by far the highest contributor to crop waste

\subsection{Crop residue management}

The majority of the households representing $48.16 \%$ indicated that they reuse residues generated from their farming activities (Table 4). Most of them feed their livestock with the straws and stalks. Burning is also a predominant management option as claimed by $27.89 \%$ of the respondents. This agrees with the work of El-Haggar et al. [8], where the researchers noted that despite the management options available to farmers in Egypt, many farmers view the practice of residue utilization as an extra cost with little financial returns and therefore the preferable way is to get rid of the residues is by dumping and open burning. About $15.26 \%$ of respondents in Ikara bury their crop residue especially in Janfalan and Saulawa wards where excavation pits are found while other management options such as dumping accounts for $8.68 \%$. From this result, it can be seen that a huge amount of residues is mismanaged by the farmers of the study area. This is because for a crop residue management to be effective it must maximize the economic benefit from the waste resource and maintain acceptable environmental standards [6].

Table 4: Disposal methods adopted by respondents in managing crop residue.

\begin{tabular}{|lcc|}
\hline Disposal methods & Frequency & Percentage (\%) \\
\hline Burning & 106 & 27.89 \\
Burying & 58 & 15.26 \\
Reuse & 183 & 48.16 \\
Others & 33 & 8.68 \\
Total & $\mathbf{3 8 0}$ & $\mathbf{1 0 0}$ \\
\hline
\end{tabular}

Source: field survey 2014.

However, Figure 3 shows that among the respondents that reuse crop waste, 94 farmers indicated that they sell them while 43 use these crop waste as cover crops, 25 use them as animal feed while the remaining 21 adopt multiple uses such as fencing of farm yards and houses, poultry mats, domestic uses etc. 


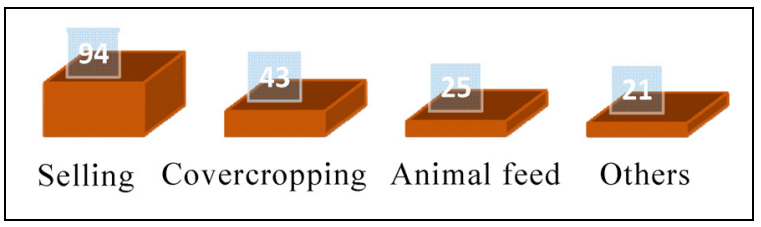

Figure 3: Reuse options of crop waste.

\subsection{Efficiency of crop waste disposal technique}

Table 5 shows the self-assessment of crop waste management methods of farmers in the study area. From the opinion the management of crop waste in Ikara is ineffective (poor and very poor) as attested by $52.36 \%$ of the respondents. This is because as indicated by Shafiul and Mansoor [17], agricultural waste forms the potential renewable energy source as biomass. Therefore, putting the huge quantities of biomass resources, mostly in the form of crop residues which are currently disposed by burning or dumping, to energy production could potentially increase the energy supply. It also confirms the statement of Jekayinfa and Omisakin [18] that agricultural waste in most developing countries, including Nigeria are not properly managed. On the other hand, 47.63\% (very good and good) indicated effective management of crop residue.

Table 5: $\quad$ Opinion of respondents on management of crop residues.

\begin{tabular}{|lcc|}
\hline Management option & Frequency & Percentage \\
\hline Very good & 105 & 27.63 \\
Good & 76 & 20 \\
Poor & 185 & 48.68 \\
Very poor & 14 & 3.68 \\
Total & $\mathbf{3 8 0}$ & $\mathbf{1 0 0}$ \\
\hline
\end{tabular}

Source: field survey 2014 .

\subsection{Factors militating against efficient crop residue management}

Having established that crop residue management techniques adopted are inefficient, the study also investigated some of the possible factors affecting the proper utilization of crop waste in the study area. The responses of the farmers are presented in Table 6 . The result shows that $31.58 \%$ reported that ignorance of the efficient/sustainable management methods and benefits of such management is the major factor as most farmers are not aware of the economic benefits of these residues such as for sale and energy regeneration and as cooking gas.

Therefore, this ignorance on the benefits of crop residues makes them to subscribe to inefficient crop residue management such as burning and open air 
dumping. Improper planning of farm yards was reported by $31.32 \%$ which indicated that some farm yards are not well situated and in some cases are too far from waste management facilities which make crop management efficiency difficult. On the other hand, $21.31 \%$ of the respondents indicated that lack of disposal facilities on the farm yards such as composting pits is a major factor militating against efficient management of crop residue. The remaining $15.79 \%$ of the respondents indicated that indiscipline of farmers is a factor affecting effective crop residue management.

Table 6: Factors affecting crop residue management.

\begin{tabular}{|lcc|}
\hline $\begin{array}{l}\text { Factors affecting crop } \\
\text { residue management }\end{array}$ & Frequency & Percentage \\
\hline Lack of disposal facilities & 81 & 21.31 \\
Improper planning of farm yards & 119 & 31.32 \\
Lack of awareness on agricultural & & \\
disposal methods & 120 & 31.58 \\
Indiscipline of farmers & 60 & 15.79 \\
\hline Total & $\mathbf{3 8 0}$ & $\mathbf{1 0 0}$ \\
\hline
\end{tabular}

Source: field survey 2014.

\section{Conclusion and recommendations}

The management of crop residues in Ikara local government area of Kaduna State appears inefficient given the multiple benefits they could otherwise provide. The current management option is not perfect and the existing framework to ensure adequate management system and the collection facilities is not available. Crop waste is still collected without separation at the source, treatment facilities are limited and the collected waste is mostly dumped haphazardly in open areas or in most cases burnt before the next farming season. Furthermore, reuse of agricultural waste will minimize cost and ensure a healthy environment for the farming communities. Based on the findings of this study, chances are that crop residue management in the study area can be improved. It is suggested that intensive mass literacy programmes on the economics of crop residue management be undertaken in the study area.

\section{References}

[1] William, P. C. Waste management. A Global Concern. New York McGraw-Hill Publisher. pp. 3-44, 2005

[2] McKendry, P. Energy production from biomass (part 1): Overview of Biomass. Bioresource Technology (83): 37-46, 2002

[3] Federal Office of Statistics (FOS). Agricultural Survey, Abuja Federal Ministry of Agriculture, 2006

[4] Fapetu, O.P. Management of Energy from Biomass. Nigerian Journal of Engineering Management (1): 14-18, 2000a 
[5] Jekayinfa, S.O. and Omisakin, O.S. The energy potentials of some agricultural waste as local fuel materials in Nigeria, Agricultural Engineering International: The CIGR E-Journal of Scientific Research and Development Vol. 7. p. 44, 2005

[6] Abebaw, D. Determinants of solid waste disposal practices in urban areas of Ethiopia: A household-Level Analysis. East Africa Social Science Research Review. 24 (1): 1-14, 2008

[7] USDA. Manure and Nutrient Management. United State Department of Agriculture,2010.http.//www.csrees.usda.gov/manurenutrientmanagement. $\mathrm{cfm}$

[8] El-Haggar, S. M., Mounir G. and Gennaro L. Agricultural Waste as an Energy Source in Developing Countries: A Case Study in Egypt on the Utilization of Agricultural Waste through Complexes. International Centre for Science and High Technology (ICS). United Nations Industrial Development Organization (UNIDO). pp. 1-10, 2004

[9] Fapetu, O.P. Production of charcoal from Tropical Biomass for Industrial and Metallurgical Process. Nigerian Journal of Engineering Management 1(2): 34-37, 2000b

[10] Kwaghe, P.V., Gwary, M.M., Abdulsalam, R.Y. and Oppong-Yeboah (2011) Economic Analysis of Agricultural Waste Management among Farming Households in Jere Local Government of Borno State, Nigeria. Journal of Agriculture and Biological Sciences. 2(6): 193-198, 2011

[11] Okoye, C. O. Hand Book on Disinfection of Sewage Sludge. Kano State University of science and Technology, Wudil Kano. p. 26, 1978

[12] Hiwassee River Watershed Coalition (HRWC). Agricultural Waste Management. Accessed from www.hrwcnet/wastemanagement.htm on 23/08/10

[13] Ayoade, J. Geography of Nigeria. Ibadan: Spectrum Books Ltd, 1996

[14] Haruna, M. Developmental Problems of the Rural Areas of Kaduna State. J. I.A. Printing Press Sabon-Tasha, Kaduna, 2007

[15] Solano, M. L., Iriarte, F., Ciria, P. and Negro, M. J. Performance characteristics of three aeration systems in the composting of sheep manure and straw. Journal of Agricultural Engineering Resource. 79(3): 317-329, 2001

[16] Adeoye, P. A., Adebayo, S. E. and Musa, J. J. Agricultural post-harvest waste generation and management for selected crops in Minna, Niger State, North Central Nigeria. Journal of Applied Sciences and Environmental Sanitation. 6 (1): 427-435, 2011

[17] Shafiul, A.A. and Mansoor, A. Partnerships for solid waste management in developing countries: Linking theories to realities in the Institute of Development Engineering, Water and Development Centre (WEDC). Loughborough University, U.K, 2003

[18] Jekayinfa, S.O. and Omisakin, O.S. The energy potentials of some agricultural waste as local fuel materials in Nigeria, Agricultural Engineering International: The CIGR E-Journal of Scientific Research and Development Vol. 7. p. 44, 2005 